\title{
Filosofie mocenské rovnováhy aneb bojovný mír podle Raymonda Arona
}

\section{Philosophy of Power Balance or Belligerent Peace According to Raymond Aron}

Jiří Nesiba / jiri.nesiba@newtoncollege.cz

Ústav humanitních věd, Newton College a.s., Brno, CZ

\begin{abstract}
Presented article puts mind to the thinking of Raymond Aron (1905-1983). Author is focused on Aron's complexive method by joining sociology, history or philosophy of history for describing international relations in four decades of Cold War how it developped from 40's to 80's of $20^{\text {th }}$ century. Aron's analyses are calling by himself as "history of presence". He described international political strategy from realistic theory of international relations. Aron studied the principles of cold war, relations between USA and USSR, nuclear armament, balance of power in bi-polar international relations, power strategic analysis and belligerent peace. He analysed international relations when the world-powers don't attack straightly and prefer conflicts in regions (sub-systems).
\end{abstract}

\section{Keywords}

Raymond Aron, Cold War, Realism, Carl von Clausewitz, theory of international relations 
Ve všech epochách se společenstvi států a povaha války navzájem ovlivñují. Společenstvi státu podněcuje určitý typ válek a určitý typ válek má vliv na organizaci společenstvi států. Tento recipročni vztah může sloužit jako základni poučka o všech historických studiich nad tématem strategie. ${ }^{1}$

Válečné uměni se změni v ostražitost a ta bude především zaměrena k tomu, aby se klesajici rovnováha znenadáni neporušila v náš neprospěch a aby se polovičatá válka neproměnila na válku dokonalou. ${ }^{2}$

\section{Bojovný mír jako princip rovnováhy}

Do jisté míry opomíjenou části díla francouzského liberálního filosofa, sociologa a historika Raymonda Arona (1905-1983) jsou jeho mezinárodněpolitické studie. ${ }^{3}$ I v dnešní době se ukazuje jeho zpơsob pohledu inspirativním. Tento článek se proto postupně po dekádách zabývá Aronovým pohledem na světovou politiku od 40. let po 80. léta 20. století. Pohled, který sám Aron nazýval jako popis tzv. dějin přítomnosti, a který jde od současnosti do minulosti, ukazuje politiku realisticky, nikoliv ideologicky. Proto se i Aron hlásil v teorii mezinárodních vztahů k tzv. realistickému směru. Jeho realismus přesahoval díky erudici do mnoha dalších oborů a analýzy byly důkladným rozborem na pomezí historie, politologie, sociologie či filosofie dějin. ${ }^{5}$ Pro samotný termín studená válka užíval termín „bojovný mír“ (fr. la paix belliqueuse). ${ }^{6}$ Proto více než třicet let po jeho smrti je zajímavé si připomenout jeho metody analýzy jako inspiraci k pochopení dnešního stavu mezinárodních vztahů. Právě v konfliktech mezinárodního prostředí se ukazuje dle Arona pravdivý obraz celé doby.

Obecně realistická teorie vycházela $\mathrm{z}$ předpokladu, že mezinárodní prostředí netvoří ani OSN či kolektivní instituce, ale tvoří jej moc a síla, v Aronově době reprezentující se v USA a SSSR (Aron obě velmoci nazýval jako Les Grands). Od politiky velmocí se podle

1 Aron, Raymond: Sur Clausewitz. Bruxelles Éditions Complexe, 2005, s. 99.

2 Clausewitz, Carl von: $O$ válce. Praha Academia, VIII, 6 A, s. 555.

3 Článek vychází z dizertační práce autora, Nesiba, Jiří: Raymond Aron o politice státu Izrael. Masarykova univerzita. Filozofická fakulta. Historický ústav. Brno 2010.

4 Realismus od 50.let 20. století nahradil idealistickou představu předválečné kolektivní bezpečnosti. Základním hlediskem realismu je, že boji o moc se nelze vyhnout. Realistická teorie mezinárodních vztahů byla prosazována politikou USA (Trumanova doktrína, Marshallův plán či politika zadržování vlivu Sovětského svazu), svůj vrcholu v americké zahraniční politice dosáhla v 70. letech, kdy ji prosazoval Aronův př́tel Henry Kissinger, srov. Petr Drulák, Petr Kratochvíl: Encyklopedie mezinárodních vztahů. Praha, Portál, 2009. Nejvýraznější vliv na Aronovo mezinárodně politické myšlení v 50. a 60. letech měl teoretik mezinárodních vztahů Hans Morgenthau (1904-1980), který mezinárodní politiku pokládá za neustálé úsilí o udržení a zvětšení moci (ve fr. překladu puissance) určitého národa a omezení moci u národů jiných, Morgenthau, Hans: Politics among Nations, The Struggle for Power and Peace. New York, Knopf, 1948. Za představitele neorealismu jako teorie války se považuje Kenneth Waltz, jehož Aron často cituje, Kenneth, Waltz: Man, State, and War. New York 1959.

5 Badie, Bertrand: Raymond Aron jako teoretik mezinárodních vztahů, Filosofický časopis, 2006, s. 163-176.

6 Drulák, Petr: Metafory studené války. Interpretace politického fenoménu. Praha 2009. 
něj odvíjí ostatní mezinárodní vztahy. Toto uspořádání tvoří stabilní systém, kterého si Aron všímal už od svého anglickém exilu během Druhé světové války, ještě před vznikem studené války. ${ }^{7}$ Mezinárodní politiku lze chápat podle vzájemného vztahu velmocí, který se následně projevuje v lokálních konfliktech (v tzv. subsystémech). Zde spolu velmoci soupeří proto, aby se vyhnuly otevřenému vzájemnému konfliktu. To že spolu státy víceméně spolupracovaly během studené války uvnitř dvou bloků a naopak soupeřily navenek, vytvářelo sice napětí ale dle Arona také rovnováhu. Prostředkem mezinárodní diplomacie by měla být právě rovnováha moci. A hledání principů rovnováhy tvořilo podstatnou část jeho rozboru mezinárodních vztahů. ${ }^{8}$

$\mathrm{Z}$ tohoto pohledu byl velmi originálním analytikem, který dokázal z jednoho subsystému vysvětlit fungování celého planetárního systému. Z jednoho lokálního politického problému dokázal vysvětlit vztah ke světové politice a k historickému vývoji. Pro svoji schopnost psát čtivě tvořil dodnes uznávané politologické úvahy do francouzských deníků. Své analýzy opíral o historický rozbor, který měl sloužit k pochopení možných tendencí budoucího vývoje. V rámci teorie mezinárodních vztahů neprosazoval obecně platnou univerzální teorii. Spíše se zabýval konkrétními oblastmi a jejich politickými problémy. Ukazoval, jak každý region má své specifické souvislosti a v kontextu mezinárodní politiky se může jevit různorodě. Pravdivý obraz je ten, který dokáže předvídat vývoj situace. Aron chápal teorii mezinárodních vztahů jako znalost, která umožňuje předvídat a podle toho jednat (fr. savoir pour prévoir et pouvoir). ${ }^{9}$

\section{Demokratické a totalitární principy}

K pochopení Aronova názoru na mezinárodní vztahy studené války je nutné se zmínit o jeho pohledu na kritiku ideologické filosofie dějin, tak jak je reprezentovali v Aronově době fašismus či komunismus. Už jako student v Německu mohl pozorovat ve 30. letech, jak vzniká ideologie a jak dokáže zmanipulovat masy občanů. Díky této osobní zkušenosti byl celý život přesvědčeným liberálem a demokratem. To i jako přríslušník asimilované židovské rodiny ve Francii odmítající z podstaty totalitární tendence, které by omezovaly svobodu jedince. ${ }^{10}$

Po celý život vystupoval kriticky k politikům, kteří omezovali veřejnou debatu levicových či pravicových, at’ ve Francii či USA nebo v Izraeli. I ve filosofii dějin odmítal zjednodušené principy ideologického popisu vývoje či zákonitostí dějin, jak tvrdila komunistická či nacistická ideologie. Odmítal ideologický pohled na historii, to i v době, kdy

7 Studie vydané po skončení války jako výbory z jeho analýz v londýnském exilu např. Aron, Raymond: L’Âge des Empires et l'ávenir de la France. Paris 1945. Týž: La Coexistence pacifique. Essai d'analyse. Paris 1953. Týž: Chroniques de Guerre. La France libre 1940-1944. Paris 1990.

8 Nesiba, Jiří: Liberální př̌stup v humanitních vědách u Raymonda Arona. Scientia et Societas VI, 2010, s. 128134.

9 Aron, Raymond: Études politiques. Paris 1972, s. 358.

10 Týž: Essai sur condition juive contemporaine. Paris 1989. 
ideologické myšlení imponovalo masám i intelektuálům na Východě i Západě ať v 30. letech nebo 60 . letech 20 . století. ${ }^{11}$

Weberovským rozdělením států podle „ideálních typů“ na státy demokratické a totalitární se snažil ukázat metodologii, jak poznat mechanismy, které totalitní státy praktikují a jak dokáží manipulovat intelektuály. ${ }^{12}$ Principy, které určují totalitární charakter státu viděl v možnost jednostranného výkladu dějin. Monopolní strana používá jedinou ideologii, která z politické strany tvoří absolutní autoritu a stává se oficiální státní pravdou, k širrení této pravdy má navíc stát monopolní prostředky, většina ekonomických a profesních aktivit je podřízena státu a stává se součástí státu samotného, jakákoliv činnost je tak vnímána ideologicky, proto i všechny chyby jsou vnímány ideologicky jako protistátní. ${ }^{13}$

Naopak demokratické režimy, které byly podle něj neustále v ohrožení ze strany totalitárních států, měly svůj specifický charakter v rozdělení moci podle politiky, kterou nazýval policy, tj. program politických stran, jak se politici a politické směry profilují ke konkrétním problémům. Jiné rozdělení moci lze pozorovat podle tzv. politics, tj. soupeření politických stran jako kolbiště názorů a dialogů. ${ }^{14}$

Právě tuto politiku ve smyslu politics chápe Aron jako základ demokracie. Je to dědictví řeckého termínu politeia, tedy politika jako střet názorů. Každá kooperace mezi lidmi obsahuje v sobě autoritu, avšak způsob, jak je autorita vykonávána, a výběr vládců jsou podstatou politiky. Politika je nejdůležitější charakteristikou celé pospolitosti, proto je podmínkou každé spolupráce mezi lidmi. ${ }^{15}$ Právě v rozmanitosti názorů a v možnosti tuto rozmanitost poznávat vnímal záruku, že není omezována svoboda jedince. Z tohoto důvodu právě mezinárodní prostředí stojí svojí rozmanitostí proti jakékoliv možnosti monopolního ideologického myšlení. Mezinárodní prostředí je tak více demokratické ve svých principech, než prostředí státní. To protože cíle politických režimů nejsou jednoznačné a nejsou nutně ve shodě. Režim, který zajištuje občanům největší prostor pro svobodu, nezajištuje vždycky největší účinnost moci, režim založený na souhlasu ovládaných neponechává vždycky držitelům moci dostatečný prostor. Na jisté rovině konkretizace jsou instituce nevyhnutelně rozmanité. ${ }^{16}$

Demokratické státy jsou zárukou svobody, z které se odvozuje nezávislý rozvoj dalších prvků svobodné společnosti. ${ }^{17}$ Naopak nedemokratické aspekty státního zřízení vedly k totalitárnímu charakteru společnosti. Totalitární režimy omezují lidskou svobodu.

11 Týž: Introduction á la philosophie de l'histoire. Paris 1938. Týž: Essai sur la théorie de l'histoire dans l'Allemagne contemporaine. La philosophie critique de l'histoire. Paris 1938.

12 Týž: Opium intelektuálů. Praha 2001.

13 Týž: Demokracie a totalitarismus. Brno 1998, s. 158.

14 Nesiba, Jiří, Hrozba ideologii a totalitarismu v dile Raymonda Arona. Auspicia VI, 2009, s. 92-102.

15 Tamtéž, s. 15.

16 Otázka nejlepšího zřízení může být kladena pouze na vysoké rovině abstrakce, v každé společnosti musí být instituce přizpůsobeny zvláštnostem jedinečné historické konstelace, tamtéž: s. 33, stejně tak jako hledání totožností v totalitárních zřízeních v historii, Aron odkazuje na debatu mezi tzv. „modernisty“ (tedy těmi, kteří tvrdí, že totalitarismus je moderní fenomén) a tzv. „primordialisty“ (totalitarismus shledávají v antické Spartě či Kalvínově Ženevě). Viz Novák, Miroslav: Mezi demokracii a totalitarismem. Aronova politická sociologie industriálních společností 20. století. Brno 2007, s. 112. 
Takové, jaké viděl od vzniku studené války v komunistických zemích, ale také v arabském světě. Záruku svobod jako zastánce etatismu vnímal jako jeden z faktorů existence suverénního státu. Mimo suverénní stát nemůže být záruka liberálních svobod. Tyto své názory potvrzoval i svým postojem, kdy se neváhal postavit proti většinovým názorům společnosti. $^{18}$

\section{Vznik rovnováhy mocenských sil}

Rozmanitost mezinárodního prostředí vede také k jisté stabilizaci, když velmoci se díky své síle udržují v napětí, které jim ale nedovolí zaútočit. Analyzování rovnováhy protichůdných (konfliktních) zájmů velmocí ukazuje charakter doby daleko realističtěji. Napětí mezi velmocemi má totiž svá pravidla v používání prostředků. Pokud by tzv. horká válka znamenala použití všech vojenských prostředků, tak studená válka znamená použití prostředků jen některých - a to převážně diplomatických vedoucích $\mathrm{k}$ lokálním konfliktům. ${ }^{19}$ Už ve čtyřicátých letech 20 . století Aron popisoval mezinárodní vztahy takovým způsobem, že upozorňoval na nový typ strategie, která vyplvývá z charakteristiky velmocí, atomových zbraní, demografických faktorů či ekonomických souvislostí. Předávlečné pojetí strategie v poválečné době přestává platit. Upozorňoval na dvě úrovně nově nastavené světové planetární diplomacie, kdy na jedné straně stojí velmoci reprezentující světovou moc (fr. puissance mondiale), které mají rozdílné zájmy od mocností regionálních (fr. puissance régionale). Může se zdát, regionální mocnosti mají samostatnou nezávislou politiku, ale taková úvaha není realistická a neodpovídá politické situaci. Zájmy velmocí se prosazují skrze zájmy regionálních mocností dle určitých pravidel. ${ }^{20}$

Dokazoval na charakteristice mezinárodních vztahů mezi USA a SSSR, že Berlínská krize v letech 1948-1949 byla ukázkou toho, co je ve studené válce dovoleno a co nikoliv. Rusové si nedovolili konflikt proti spojeneckým letadlům a USA se nedopustily ničeho proti sovětským zátarasům na silnicích a železnicích, protože vzájemné soupeření použití ozbrojené síly vylučovalo. Tradiční pojetí míru znamenalo omezení diplomacie ve dvojím směru: jednak se snížila závažnost konfliktů mezi státy, ale zároveň se omezily vynakládané prostředky na udržování napětí. Ve studené válce naopak státy zvyšují náklady na udržování napětí, ale kde mír už není možný. Absence míru nemusí vést nutně k válce. ${ }^{21}$

Nejpřesnější charakteristiku dobu počátku studené války viděl v premise, že mír je nemožný, ale válka nepravděpodobná. Atomové zbraně zachovávají vyváženost systému.

18 Týž: Leçon sur histoire. Cours de Collége de France. Paris 1989. Týž: Les derrniéres années du siécle. Paris 1984.

19 Aron, Raymond: Les chances d'un règlement européen. Politique étrangère 14, 1949, p. 249-262, [online], (cit. 15.6.2009), dostupné z http://www.persee.fr/web/revues/home/prescript/article/polit_0032-342x_1949_num_14_3_2808.

20 Baverez, Nicolas: Raymond Aron. Un moraliste au temps des idéologies. Paris 1993, s. 213.

21 Aron, Raymond: Historie XX. stoleti. Praha 1999, s. 223. Podobně jako britský historik Eric Hobsbawn i Aron tvrdil, že studená válka konzervovala stav politického napětí a až po jejím skončení se opět politické procesy vrátí do přirozeného stavu, srov. Hobsbawn, Eric: Věk extrémů: krátké 20. století 1914-1989. Praha 2001. 
Dobu studené války popisoval tedy jako bojovný mír. ${ }^{22} \mathrm{~V}$ době rozdělení sféry vlivu mezi USA a SSSR právě demokratický západní svět podle Arona zbytečně podlehl obavě z konfliktu se SSSR a Východní Evropa tak spadla celá do sféry vlivu Moskvy. Varoval od 50. let 20. století, aby se podobná situace neopakovala i v koloniích třetího světa, které si západní státy chtěly i vojenskou silou podržet, a tak získával Sovětský svaz nové spojence, kterým v rámci lidově demokratického osvobozeneckého boje slibuje podporu za jejich boj o samostatnost. Protože moc států se tedy odvíjela od moci velmoci, s kterou stát spolupracoval.

\section{Války v řetězech}

Od padesátých let 20. století Aron analyzuje jednotlivé regiony, kde probíhaly lokální konflikty. Obě velmoci zformovaly určité principy, jakým způsobem spolu soupeří. Jedním z hlavních je fakt, že nepoužijí atomové zbraně, že nevstoupí do vzájemného konfliktu přímo. Dalším rysem je fakt, že jak Washington, tak Moskva jednají podle realistické mocenské diplomacie, která není založena na ideologickém přesvědčení. Oběma blokům jde o rozšíření sféry svého vlivu (v Evropě, v Africe, na Blízkém východě), a proto musí dodržovat taková pravidla, aby mezi nimi nevznikla přímá válka. ${ }^{23}$

Tato „atomová doba“ nicméně dokazuje, že lokální konflikty nadále budou existovat i v prostředí nebezpečí vzniku totální atomové války. První ukázkou tohoto planetárního systému se počátkem padesátých let stala válka v Koreji. Její charakter vnímá Aron jako způsob, kterým se budou odvíjet i další konflikty mezi velmocemi. Tedy skrze třetí státy a posilování sféry vlivu v nich. Podle Arona studená válka a její „mírová koexistence“ je způsobem této směsi nepsaných dohod a otevřené rivality. Udržování určitého napětí mezi velmocemi umožňuje to, že rivalita velmocí nesklouzne k totální válce, ale ani nevznikne dohoda o rozdělení světa na sféry vlivu, která by zaručila mír. Taková dohoda by legitimizovala ideologie. Podle Arona studená válka není konfliktem ideologií, ale je to mocenský boj. V množství článků a analýz dokazoval toto svoje tvrzení na konkrétních příkladech světové politiky, jak tento boj probíhá např. ve francouzské kolonii v Indočíně, v Maghrebu, v Alžírsku či na Blízkém východě. ${ }^{24}$

22 Aron, R.: Le Grand, s. 231. Podle Arona bojovný mír byla i doba 30. let 20. století v Evropě, kdy ale západní státy nevytvořily rovnováhu Německu (např. v roce 1936) a to z pozice dominantního jediného hegemona mohlo zaútočit s jistotou převahy.

23 Aron, Raymond: Le dialogue des Quatre sur l'Allemagne. Politique étrangère 17, 1952, p. 135-142, [online], (cit. 9. 9. 2010), dostupné z www.persee.fr/web/revues/home/prescript/article/polit_0032-342x_1952_ num_17_3_6209. Pro zkoumání pravidel bojovného míru Aron navrhuje metodiku, např. podle klasifikačního modelu určuje 6 okruhů, podle nichž lze sledovat zahraniční politika studené války padesátých let: 1 . Podle stanovení pole diplomatických aktivit (limity diplomatického systému), 2. Vztahy moci (fr. puissance) neboli koncepty rovnováhy, 3. Určení druhů (fr. technique) vztahů mezi státy (mírové či válečné) neboli určení druhủ diplomacie a války, 4. Vzájemné uznání či neuznání mezi státy, 5. Určení vztahu mezi vnitřní a vněǰší politikou státu, 6 . Určení smyslu a cíle zahraniční politiky, srov. Týž: De l'analyse des constellations diplomatiques, Revue française de science politique 4, 1954, p. 237-251, [online], (cit. 1.6.2009), dostupné na http://www.persee.fr/web/revues/home/prescript/article/rfsp_0035-2950_1954_num_4_2_452646. 
Ani jedna velmoc se vlastně dohodnout nechce, protože existence bloků zajištuje vždy možnost získat nové spojence a oslabit tak soupeře. Vyrovnanost soupeření velmocím brání, aby společně prosazovaly nějakou vzájemnou dohodu. Jednání o dohodě započnou, až jedna z velmocí bude slabší než druhá a bude tak mít zájem na domluveném uspořádání. Bipolární svět tak přispívá ke vzniku stavů, které zjevně odporují zdravému rozumu, ale vyhovující mezinárodním zájmům velmocí. ${ }^{25}$

Ačkoliv politiku Spojených států vnímal jako mocenskou diplomacii, vyzdvihoval jejî charakter založený na liberálních a demokratických základech. Protože se americká diplomacie odvíjí od strategie, kterou mohou vlastní občané ovlivňovat, tak pro Arona je to dostatečným signálem demokratické záruky. Proto preferoval užší spolupráci mezi demokratickými zeměmi v Evropě se Spojenými státy, aby se obnovovala hráz proti tendenci zvětšování vlivu Moskvy ve světě. Touto cestou lze vyrovnávat zvyšující se moc SSSR a vyrovnávat planetární rovnováhu rozdělení sily. ${ }^{26}$

Vlastnictví atomové zbraně velmocemi je dostatečnou zárukou obrany celého bloku. Do logiky studené války další země s atomovou zbraní nepřinášejí nové rozdělení moci. Planetární systém je závislý na krocích velmocí, vojenské reakce malých států vedoucí k nějakému atomovému konfliktu bez vědomí velmocí jsou systémem studené války blokovány. Obě velmoci udržují v oblasti status quo a podporují ty země, které vnímají jako součást své sféry vlivu a diplomacie soupeření prodlužuje napětí a nepřispívá k uvolňování. ${ }^{27}$

Aronova studie Války v řetězech studenou válku vysvětluje jako dědictví předešlých světových válek, kdy studená válka je novým stupněm války. ${ }^{28}$ Studená válka je čekáním na chybu soupeře, jenž se zaplete do nějakého lokálního konfliktu, který by jej výrazně oslabil, a tak v jiné části světa ztratí vliv, a druhá velmoc toto oslabení využila k posílení svého postavení. ${ }^{29}$ Aron se odvolával na dialektickou metodu, kdy navzájem konfrontoval různé pohledy na zkoumanou látku a srovnával je s realitou. Konflikty a války se tak jeví nikoliv jako zákonitosti historického vývoje, ale jako důsledky strukturálních změn

25 Tamtéž, s. 288. V terminologii vojenské strategie se v počátcích studené války ustálily dva stupně odvety v případě konfliktu: 1. Graduated deterrent - stupňovaná odveta úměrná agresi (v této fázi se počítalo se zastrašováním atomovými zbraněmi), a 2. Great deterrent - globální konflikt.

26 Pro francouzskou společnost byl Aron provokativní, když tvrdil, že USA by měly být v historickém kontextu nejbližším spojencem Francie. To, že tomu tak není, je chybou obou států (spojenectví od dob boje amerických kolonií za samostatnost, politika Napoleona a jeho prodej Louisiany, aby vytvořil konkurenta Velké Británii, přes inspirace americkou demokracií při vzniku Třetí francouzské republiky, či pomoc během První i Druhé světové války, podle Arona Francie měla v novodobé historii v Evropě konkurenty, ale v USA partnera), srov. Aron, Raymond: La Diplomatie Américaine. In: George F. Kennan: La Diplomatie Américaine 1900-1950. Préface par Raymond ARON. Paris 1952.

27 Týž: Polemique. Paris 1955.

28 Týž: Les Guerres en chaînes. Paris 1951.

29 Podle Arona klasické vojenské strategie hovořící o absolutní vojenské porážce nepřítele v době studené války již neplatí. Ukazuje se nadřazenost politiky nad vojenstvím (jak tvrdil i Clausewitz), válka v Koreji dokázala, že studená válka je válkou omezenou, kdy velmoci nevyužijí všech svých prostředků, tento stav může trvat generace, srov. Aron, Raymond: De la paix sans victoire. Note sur les relations de la stratégie et de la politique. Revue française de science politique 1, 1951, p. 241-255, [online], (cit. 5. 1. 2010), dostupné z http://www.persee.fr/web/revues/home/prescript/article/rfsp_0035- 2950_1951_num_1_3_392080. 
ve společnosti nebo jako otázka lidských vášní. Nikoliv jako dějinná zákonitost, jak viděli historický vývoj marxističtí oponenti. ${ }^{30}$

Charakter mezinárodního prostředí dokazuje, že ideologii lze jen předstírat, ale nelze podle ní jednat. Ideologie se musí adaptovat na mezinárodní prostředí a jednat podle mechanismů jako každá jiná země. Podle Aronových analýz v této době právě tlak a soupeření na mezinárodním poli ukazuje, že komunistické státy ovládané uvnitř komunistickou ideologií nemohou dlouhodobě soupeřit se západními demokratickými zeměmi. Komunistická ideologie se prezentuje v mezinárodním prostředí „bojem za mír“, ale její politika je čistě realistická a mocenská. Totalitární komunistické režimy rozloží hlavně ekonomická neefektivita jejich hospodaření. Sovětský svaz může efektivně rozšiřovat svou moc jen do několika zemí, které bude uplácet svým nerostným bohatstvím a hospodářskou spoluprací. ${ }^{31}$

Diplomacie se stala po válce globální záležitostí, celý svět je rozdělen do bloků a jakákoliv změna konfigurace mocenského vztahu se projeví v celém systému světové diplomacie (fr. diplomatie mondiale). Dvě supervelmoci mohou vojensky kdekoliv ve světě zasáhnout, tedy disponují prostředky tzv. totální diplomacie (fr. diplomatie totale). Právě tato totální diplomacie vytvořila svět takový, že mezinárodní vztahy a politika každé samostatné země je závislá na faktu, ke kterému z dvou bloků patří. Podle Arona nikdy nebyl počet samostatných, ale politicky závislých států tak vysoký. ${ }^{32}$

Na příkladu panarabského hnutí ukazoval nekompetentnost těch západních politiků, kteří nevnímají perspektivu celého arabského regionu. Někteří politici věnují pozornost Blízkému východu proto, že je to z hlediska západních ekonomických zájmů „vyhrazeným prostorem“ (fr. chasse gardée). Francie ani Velká Británie svou koloniální politiku nezaložily na rozvoji regionu, ale na ekonomických jednostranných zájmech. Tím vlastně způsobili, že se panarabské hnutí z logiky strategie přiklonilo na stranu SSSR. Navíc umělým rozdělením bývalých mandátních území Francie a Velké Británie tak vznikl stav, který položil základy nenávisti mezi Židy a Araby, který v 19. století ještě neexistoval. Podporovat tuto koloniální politiku i nadále znamená prohlubovat konfliktní situaci, která se obrátí proti Západu. ${ }^{33}$

Suezská krize v listopadu 1956 jako důsledek sovětské okupace Mad’arska i názorně ukázala slabost politiky Francie a Velké Británie a dostala mezinárodní politiku na hranu

30 Baverez,: Raymond Aron, s. 255.

31 Aronova studie úvah na toto téma nevyšla původně pod Aronovým jménem, ale pod pseudonymem François Houtisse, srov. Houtisse, François: La coexistence pacifique. Essai d'analyse. Monde nouveau, Paris 1953. Aron v množství článků popisoval mechanismy napětí mezi velmocemi a státy, které jsou podle povahy mezinárodního prostředí donuceny k egoistickému realistickému chování. Idealistické koncepce se snaží vnutit mezinárodnímu prostředí nějaké principy a to podle Arona degraduje v imperialismus, srov. Aron, Raymond: En quête d'une philosophie de la politique étrangère. Revue française de science politique, vol. 3, n¹, 1953, p. 69-91, [online], (cit 24. 4. 2010), dostupná na http://www.persee.fr/web/revues/ home/prescript/article/rfsp_0035-2950_1953_num_3_1_452691.

32 Aron, Raymond: La société industrielle et la guerre. Paris 1959, s. 91.

33 Tamtéž, s. 145. 
velkého konfliktu (angl. Brinkmanship). ${ }^{34}$ Podle Arona je arabský názor na vznik Izraele jako důsledků koloniální politiky evropských mocností oprávněný. Židovský stát vznikl $\mathrm{z}$ arabského pohledu účelně a uměle na bývalém britském mandátním území proti vůli místních obyvatel. Proto jeho vznik vyvolává v arabském světě takovou negativní odezvu. Proto vznikl blok arabských států, který nesouhlasí s jeho existencí. Blok arabských států udržuje permanentní napětí a velmoci toto napětí využívají ke své planetární diplomacii. Složitost vztahů na Blízkém východě podle Arona vyplývá z toho, že na jedné straně jsou kritizováni ti, kteří pokračují v koloniální politice (fr. vieux riches), jako je USA či Izrael. Proti nim stojí nově konstituované arabské střední třídy (fr. nouveaux pauvres) podporované Moskvou. I nejchudší Arabové jsou v rámci ideologické manipulace utvrzování v představě, že jsou nespravedlivě vykořistovaní, přičemž jejich chudoba je dávána za vinu vzniku státu Izrael. ${ }^{35}$ To, co je spojuje do představy „národa“ a do společného arabského bloku, je představa nepřítele, kterého vidí v západních státech.

Aron si už od padesátých let uvědomoval tragické důsledky izraelsko-palestinského soužití. Izraelci obývají území, které palestinští Arabové považují za své. Jak Židé, tak Palestinci nemají jiné „náhradní území, proto se Aron obává stavu, kdy oba národy budou odhodlány bojovat na život a na smrt, jedni proto, aby si svou zemi udrželi, druzí proto, aby ji znovu dobyli. Už v padesátých letech Aron ř́ikal: neptejme se, kdo má pravdu, protože Židé i Arabové mají dobré argumenty, ale vnímejme perspektivu tohoto regionu. ${ }^{36}$

Podle něj se na židovsko-palestinské vztahy můžeme v této době podívat optikou soužití menšiny s většinou. Příkladem je pro něj správa francouzských kolonií, především v Alžírsku. Příčiny konfliktu lze sledovat v ekonomických vztazích, kdy kolonizátoři na jednu stranu zvyšují ekonomický výkon celé oblasti, ale na druhé straně ovlivňují nové demografické trendy. Na jednu stranu bohatne elita ( $\mathrm{tj}$. nově příchozí obyvatelé z Evropy), na straně druhé se nejchudší vrstvy stávají demograficky dominantní složkou společnosti. Elita podporuje nespravedlivé rozdělení nabytého bohatství. I když část ekonomických výhod k původním obyvatelům dorazí, ti si přesto uvědomují status nejchudší vrstvy. Tento stav vede nejen k revoltě proti kolonizátorům, ale také k nemožnosti integrace obou skupin. Ekonomický rozvoj na ovládaných územích podporuje národnostní osvobozenecká hnutí. Proto dlouhodobě nelze kolonizovat cizí území, kde žijí původní obyvatelé nepřátelští ke kolonizátorům. Což platí jak pro Francouze v Alžírsku, tak i pro židovské osadníky na arabském území. ${ }^{37}$

Původní obyvatelé se na novém bohatství podílejí omezeně. Proto Aron stále zdůrazňoval nutnost rozdělení Izraele na dva státy - palestinský a židovský. Suverenita domácího původního obyvatelstva se stává hlavním cílem politického boje bez ohledu na ekonomické či sociální dopady. Aron tvrdil, že nacionalismus je určitá vášeň, veškerá „národněosvobozenecká“ politika se v takovém případě zjednodušuje neustálým svalováním

34 Týž: Paix et guerre entre les Nations. 1962, s. 472. Angl. termín brinkmanship znamená „politika na okraji války“, „hra s ohněm“.

35 Týž: La société industrielle et la guerre, s. 149.

36 Týž: Historie XX. soletí, s. 321.

37 Týž: L'Algérie et la république. Paris 1958, s. 34. 
viny na kolonizátory. ${ }^{38}$ Dle Arona se uznáním samostatného palestinského státu dostávají konflikty pod větší kontrolu. Stát na mezinárodním poli již nemá tak volné ruce jako národ bojující za svoji samostatnost.

\section{Válka a mír mezi národy ve stínu atomových zbraní}

Začátkem šedesátých let se Aron věnoval intenzivněji analýze mezinárodních konfliktů souvisejících se strukturální změnou společnosti jak v západních zemích, tak hlavně v zemích třetího světa. V té době rozpracovával dále svoji teorii tzv. industriální společnosti jako důsledku demokratizačního procesu. ${ }^{39} \mathrm{~S}$ koncem koloniálního světa se ukazovaly nové perspektivy světové politiky pro rozšíření demokratických států. Zároveň dle Arona pokud zkoumáme mezinárodní vztahy povrchně lze se domnívat, že pominulo od 60 . let nebezpečí přímého atomového útoku. Ale tento stav se nemění od vzniku bojovného míru v 50. letech. Toto není ta zásadní změna mezinárodní politiky. Čím více se mluví útočněji, tím je evidentnější snaha zastrašit protivníka. Zde je třeba dle Arona hledat principy mezinárodní politiky. Oba bloky mluví jinak ke svým občanům a jiný význam má jejich politika na mezinárodním poli. ${ }^{40}$

Existují tři názory na moderní konflikty. Optimisté věří, že riziko atomového konfliktu utlumí výsledky lokálních konfliktů. Naopak pesimisté předvídají rozvinutí lokálních konfliktů do konfliktu atomového. A konečně realisté, kam Aron řadil i sebe. Po vzoru sociologické teorie konfliktu tvrdí, že konflikty jsou přirozené, protože ventilují hromadící se napětí ve společnosti. Lokální konflikty proto mohou snižovat riziko konfliktu globálního. ${ }^{41}$

Sociologickým konceptem tzv. „industriální společnosti“ Aron vysvětloval změny v mezinárodní politice v 60. letech. Přirozenou svobodnou cestou industrializované hospodářství vytváří demokratické a liberální mechanismy ve společnosti. Tato industrializace je následně doprovázená demokratizací společnosti a tento proces se děje nejefektivněji uvnitř hranic států, kde je již ukončená fáze národního sebeuvědomění. Proto se vyvíjejí paralelně ekonomie i demografie a nacionalismus. Národně osvobozenecký boj tak vytváří v západních demokratických zemích nepřítele demokracie ve třetím světe.

Aron se snažil dokázat, že efektivní a předvídatelné fungování celosvětových mezinárodních vztahů je možné tehdy, když v rámci celoplanetárního systému budou účastny jen suverénní samostatné státy, které budou založeny na národnostních idejích přelo-

38 Týž: La tragédie algérienne. Paris Plon, 1957, s. 35.

39 Týž: Dix-huit leçons sur la société industrielle. Paris Gallimard, 1963. Týž: La lutte des classes. Nouvelle leçons sur les sociétés industrielles. Paris 1964. Týž: Note sur le pouvoir économique. Revue économique 9, 1958, p. 849-858, [online], (cit. 7. 12. 2009), dostupné na http://www.persee.fr/web/revues/home/prescript/ article/reco_0035-2764_1958_num_9_6_407330.

40 Týž: Science et théorie de la politique. Revue française de science politique 11, 1961, p. 265-266, [online], (cit. 24. 4. 2010), dostupné na http://www.persee.fr/web/revues/home/prescript/article/rfsp_0035-2950_1961_ num_11_2_392619.

41 Týž: Le Grand Débat. Initiation á la stratégie atomique. Paris 1963. 
mu 19. a 20 století. Tento proces by měly západní státy podporovat a nezvětšovat tak sílu sovětského bloku. Obhajoval etatismus, nadřazenost státu nad národem. V systému, kde existují samostatné státy, lze formovat vědu o těchto mezinárodních vztazích a lze i poznat aktuální politickou sílu v mezinárodním prostředí. Proto Aron napsal svoji neznámější učebnici mezinárodních vztahů Mír a válka mezi národy, kde konflikty jsou konflikty jen mezi státy a tak se ukazuje moc každého státu (fr. force de frappe ). ${ }^{42}$ Nelze ale vést efektivně dlouhodobě partizánskou válku s nepřítelem, který nemá svůj stát a není podřízen mocenským pravidlům mezinárodního prostředí (např. terorismus)

Svým důrazem na „etatismus“ a úlohu státu v mezinárodním prostředí překonává rozpor mezi idealismem a realismem. Podle něj obě teorie nemusí být z principu protichůdné, ale z určitého ohledu se mohou doplňovat. Podobně jako sociologická analýza a racionální schematismus mohou dohromady vytvořit souvislý popis společnosti. Nelze je tedy redukovat na dialog mezi realistickým machiavelismem a idealistickým moralismem. Spíš je třeba se zaměřovat na podstatu mezinárodních vztahů. Mezinárodní vztahy jsou sice podle své definice vztahy mezi národy, ale význam národ chápe jen jako politické společenství územně uspořádané do státu. Tedy mezinárodní vztahy jsou vztahy mezi politickými, zeměpisně uspořádanými jednotkami. Lze je tedy nazvat spíše vztahy mezistátními (fr. interétatiques). ${ }^{43}$

Každý stát se řídí politikou vnitřní (vnitřní zákonodárství) a vnější (moc státu prosadit se navenek). Stát má monopol slovy weberovské terminologie na legitimní násilí. Ve státě jsou občané podřízeni stejnému právu a zákonům. Nicméně na mezinárodním poli na jedné straně státy nejsou podřízeny vždy stejně vymahatelnému právu, ale na straně druhé státy spolu sousedí a nějaké vztahy mezi sebou mít musejí. Zde se otvírá nová úroveň politiky, a právě zde je prostor pro vědu o mezinárodních vztazích, jejichž praktické využití lze pomocí praxeologie aplikovat v otázkách strategie. Důrazem na otázky strategie a taktiky diplomacie se oba směry, at realistický či idealistický, přibližují k podobným metodám výzkumu a jejich rozpor se zmenšuje. ${ }^{44}$

Mezinárodní vztahy podle Arona prezentují přirozený stav tak, jak jej definovali klasičtí političtí filosofové Thomas Hobbes, John Locke či Jean-Jacques Rousseau ve svých teoriích „společenské smlouvy“. Tento přirozený stav, který byl podle nich na základě občanské smlouvy v každém státě nahrazen stavem občanským, je legitimní autorita díky státním institucím zaručená. ${ }^{45}$

42 Týž: Paix, s. 156.

43 Tamtéz̆, s. 17.

44 Tamtêz, s. 19; Clausewitzovu strategii chápe Aron jako umění diplomacie, které vede k zabránění války diplomatickými prostředky. Praxeologie je věda, která analyzuje lidské jednání v konkrétních situacích, často se jejích výsledků odvolává ekonomie, jejím zakladatelem byl rakouský ekonom a představitel tzv. Rakouské ekonomické školy Ludwig von Mises (1881-1973). Aron ukazuje na př́kladu praxeologie mezinárodních vztahů rozpory mezi teorií a praxí, na jedné straně historie dokládá, jak lidé jednají násilně (předpoklad realistů) i když obecný ideál byl vždy pacifistický (předpoklad idealistů), srov. Aron, R.: Paix, s. 567-596.

45 Z klasiků novověké filosofie si Aron cení liberály oslavovanou studii Davida Huma On the balance of power. Srov. Hume, David, On the balance power. In: Hume, David: Essays, moral, political and literaly. Part II. Indianapolis 1987. 
Protože válka mezi státy je posledním nástrojem politiky, je podle Arona potřeba vědy o vztazích mezi státy, která poslouží $\mathrm{k}$ tomu, aby bylo válce zabráněno. Je tedy potřeba vytvořit takovou strategii, která by diplomacii dala nástroje, jak se válce vyhnout. Výběr konkrétní strategie závisí podle Arona jak na cílech politiky, tak i na dostupných prostředcích, jak takového cíle dosáhnout. Po zkušenostech studené války, kdy součástí soupeření byly nejrůznější strategické psychologické metody, nevnímá Aron válku jen jako fyzický násilný boj. Právě díky strukturálním změnám se tento typ konfliktů bude čím dál více rozvíjet a bude se v něm projevovat velmocenský boj. ${ }^{46}$

Klasická úvaha, že síla a úroveň diplomacie je založená na síle vojenských prostředků, které má stát k dispozici, se proměnila. Do vynálezu atomových zbraní byla diplomacie a strategie založena na koordinaci a velikostí armády, která byla od prostředků diplomacie neoddělitelná. Velikost konfliktu odpovídala nasazení odpovídající fyzické vojenské síle. S možností použití atomových zbraní se pozměnily i možnosti diplomacie. ${ }^{47}$

Cílem politiky jednotlivých států je složitě definovatelná instituce moci (fr. puissance). Moc Aron vnímá v dialektickém vztahu, který nelze přesně určit pro všechny typy mezinárodních vztahů (moc je vždy závislá na aktuálním stavu politické jednoty, politické kultury, ekonomie). Moc lze jen poznat, jak se vyvíjí, jak se proměňuje v konfliktech s jinými, nikoliv jako statická veličina. ${ }^{48}$

Moc je založená na síle, tedy na všech prostředcích, které má stát k dispozici pro prosazení své moci. Míra této síly se pozná ale jen na mezinárodním poli. Stát pozná velikost síly jen v systému mezinárodních vztahů, jak tuto sílu (ne)uznávají ostatní státy. Prostředky síly mohou být různé - vojenské, ekonomické či politické, ale pokud jen mají význam v mezinárodním prostředí, lze je nazývat politickou silou. Podle Arona jen prostředky zahraniční politiky ukazují reálnou moc státu (fr. pouvoir). ${ }^{49}$

Aron dělá vlastní klasifikaci rozdělování typů diplomacie (fr. types diplomatie), styly diplomacie (fr. diplomatie styles) či prostředky diplomacie (fr. diplomatie moyens). Věrný klasické sociologii každou z těchto kategorií člení na další podkategorie podle způsobu sociologického členění weberovských ideálních typů..$^{50}$ Tento klasifikující přrístup, kterým se snažil vysvětlit možné podoby mezinárodních vztahů, je dnes nevyužívaný a meziná-

46 Aron, R.: Paix, s. 42-48.

47 K otázce změny chápání mezinárodních vztahů v době atomových zbraní přispěl velkou měrou teoretik války „neoclausewitzián“ Herman Kahn, který se podobně jako Aron inspiroval klasickými strategickými úvahami o vojenství u Clausewitze. Kahn, Herman: On Thermonuclear War. Princeton 1960.

48 Aronův realismus se projevoval v jeho názorech, že „power politics“ neboli „Machtpolitik“ (termín, který zavedl německý historik Heinrich von Treitschke v druhé polovině 19. století) není v době studené války žádnou hodnotou, ale faktem. Nicméně Aron nepovažuje armádu za jediný nástroj realistické politiky jako ostatní čelní američtí pragmatici realistického směru, armáda je zárukou, která by podobně jako atomová zbraň měla sloužit jako odstrašovací prostředek, Aron, Raymond: Peace and War: A Theory of International Relations. New York 1966, pp. 591-600, [online], (9. 6. 2010), dostupné na http://www.mtholyoke.edu/acad/intrel/aron.htm.

49 Tamtéż, s. 65. Př́íladem špatného pochopení rozložení moci může podle Arona posloužit francouzská zahraniční politika v předvečer druhé světové války, kdy Francie chtěla působit jako světová mocnost hrdá na mezinárodní smlouvy, které však opomenuly realitu a Německo získalo v důsledku nad Francií tak velkou převahu, že ji v roce 1940 bez větších problémů vojensky porazilo. Srov. Tamtéž, s. 69.

Tamtéz̆, s. 69-72. 
rodní politika využívá aktuální studie ad hoc ke každému konkrétnímu případu zvlášt. Chybí tak jednotný výklad a možnost porovnání a ztrácí se znalost souvislostí.

Aron prezentoval teorii mezinárodního systému a subsystému․.$^{51}$ Systémy jsou homogenní (státy stejného typu, řídící se stejnými politickými koncepty, např. státy po Vídeňském kongresu v roce 1815 nebo státy uvnitř jednoho bloku) a heterogenní (ř́ídí odlišnými zájmy a jsou řízeny podle principů, které mají jiné hodnoty, jiné souvislosti a jiné způsoby pochopení vztahů). ${ }^{52}$

V době studené války se většina států pohybuje dle něj právě v heterogenním systému. Nemají žádnou trvalou záruku v mezinárodním právu a mezinárodních institucích, a musejí spoléhat jen na svoji sílu a moc. Záruku míru či předvídatelnost vývoje vidí v mezinárodním uspořádání, které ctí suverénní a samostatné státy. Existence suverénních samostatných států je trvalou zárukou, že mezinárodní systém bude podřízen jednotnému principu. Soupeření států v heterogenním systému totiž nemůže mít nikdy absolutního vítěze. Je to neustálý proces. ${ }^{53}$

Stát je jediným legitimním aktérem, který může bojovat o vliv s jinými státy na mezinárodním poli. Tak je zajištěno, že žádný ze států nemá monopol na výklad mezinárodního práva. Nadřazenost státu nad národem je způsobena faktem, že všechny národy se dovolávají národnostního principu. Určitý druh napětí vyplývá z faktu, že jsou národní státy v menšině. ${ }^{54}$

I heterogenní systém se dělí na dvě roviny, tzv. planetární systém (vztah mezi velmocemi), a regionální systém (vztah velmoci k regionu). Planetárnímu systému jsou podřízeny jednotlivé subsystémy ve světových regionech (prříkladem subsystému může být právě region Blízkého východu). Vždy má ale hierarchickou podobu. Např. v subsystému „Blízký východ“ (tj. Izrael a okolní arabské země) je hlavní charakteristikou existence permanentního konfliktu. V šedesátých letech viděl hlavní vinu ve faktu, že arabské státy nechtějí Izrael uznat jako suverénní stát a nechtějí uznat jeho právo na existenci. Kdyby nepřátelské arabské státy měly sílu, zničily by Izrael. Proto je Izrael v rámci svého subsystému napojen na pomoc západních velmocí, kdežto arabské státy nepřátelské k Izraeli jsou spřáteleny se Sovětským svazem (což se ale v budoucnu může změnit). Aron charakterizuje hlavní problém ve faktu, že cílem Izraele je uznání své suverenity od arabských zemí, cílem arabských zemí je zničit Izrael. Právě přítomnost velmocí v regionu vytváří v tomto subsystému rovnováhu soupeřícím stranám a zachovává také status quo. ${ }^{55}$

Vlastnictví atomové bomby, o kterou usilují Francie či Velká Británie (ale i Izrael), považuje Aron za neefektivní krok a nepochopení principu studené války. Moc a síla států se neodvíjí od vlastnictví atomové zbraně, ale od vztahu k velmocím, které atomovou zbraň už vlastní. Atomové zbraně slouží jako hrozba ostatním státům a nikoliv jako zbraň, kterou by některý stát mohl použít (angl. MAD - Mutual Assured Destruction). Ten,

51 Tamtéž, s. 104.

52 Tamtéž, s. 108-111.

53 Tamtéž, s. 76.

54 Týž: Dimensions de la conscience historique. Paris 1961. Aron, R.: Historie XX. století, s. 61.

55 Týž: Paix, s. 387. Heckschner, August: Diversity of Worlds. France and the United States Look Their Common Problem. New York 1957. 
kdo by ji použil jako první, bere na sebe rizika atomové odvety, která znamená zničení planety, což žádná z velmocí neudělá (angl. no first use). Vědomí zničení celé planety při použití jaderných zbraní vede $\mathrm{k}$ faktu, že žádná ze stran se neodváží je přímo použít. Jaderné zbraně slouží podle Arona maximálně k zastrašování protivníka a $\mathrm{k}$ podpoře partnerů v lokálních konfliktech. ${ }^{56}$

Zásadním faktem studené války je skutečnost, že atomové zbraně nebyly během studené války zatím nikdy a nikde použity (a to ani při konfliktech v Koreji, Mad’arsku, během Sinajské či Kubánské krize nebo během války ve Vietnamu). Podle Arona tak je legitimní úvaha, že atomové zbraně nejsou ničím více než jedním z prostředků diplomacie. Ten, kdo podlehne hrozbě nebezpečí jejich použití jako první, je při svém rozhodování v nevýhodě. Paradoxně toto „diplomatické využití“ jaderných zbraní rozložilo moc mezi velmoci rovnoměrně. Podle Arona přineslo jistou stabilitu celoplanetárního systému. Raymond Aron tvrdí, že atomové napětí udržuje planetární mír. Otázkou zůstává, co se stane, když atomovou bombu získají noví hráči mimo velmoci - státy, které nemají zkušenost $\mathrm{s}$ tím, že se stanou nukleární mocností. Aron mluví o narušení symetrie a vzniku nového typu napětí, kdy trpaslíci donutí jednat obry. ${ }^{57}$

Obecně vlastnictví jaderného arzenálu souvisí i s nutným dalším jaderným vývojem, který stojí nemalé finance. Jaderné zbraně slouží lokálním státům pro pozvednutí politického sebevědomí, které ale nelze přenést dlouhodobě do reálné politiky. Spíše než že by způsobovaly války, atomové zbraně vyhrocují krize. ${ }^{58}$

Koncem padesátých let ve spolupráci s Moskvou připravoval svůj jaderný program i Egypt. Logika atomového soupeření napovídá, že vlastnictví atomových zbraní donutí protivníka, aby si atomové zbraně pořídil také. Tím se opět nastoluje rovnováha - každý stát si musí být vědom nebezpečí možné odvety. Vzhledem $\mathrm{k}$ malé rozloze Izraele by stačilo, aby Egypt věděl o izraelské jaderné ponorce Polaris, způsobilé případný jaderný útok Egyptu vrátit. Vlastnictví atomových zbraní by se z dlouhodobého hlediska stalo neefektivním. ${ }^{59}$ Aron nepochybuje, že kdyby atomovou volbu v závěru Druhé světové války mohl použít Hitler, použil by ji. Tento akt by nebyl strategickým racionálním uvažováním mezinárodní politiky, ale bojem chorého nemocného člověka, který zfanatizoval davy. $\mathrm{V}$ př́padě možnosti rozhodování o použití atomových zbraní u takových politiků, jde teorie stranou. Proto s poukazem na mezinárodní vztahy, upřednostňuje systém,

56 Strategie zastrašování (angl. deterrence) byla popsaná poprvé americkým diplomatem v SSSR George F. Kennanem (1904-2005), který popisoval stalinskou atomovou mašinerii jako strategickou hru, nikoliv jako reálnou hrozbu předstupně válečného konfliktu na základě komunistické ideologie.

57 Aron, Raymond : The Great Debate. Theories of Nuclear Strategy. New York 1965, s. 196. Proto Aron nesouhlasil s de Gaullovým úsilím o získání jaderné zbraně pro Francii, která není podle Arona světovou mocností. Světu rozděleném na bloky zajištuje stabilitu vlastnictví zbraní pro velmoci, jak budou získavat atomovou zbraň i ostatní státy, prohloubí mezinárodněpolitickou nestabilitu v subsystémech. Tamtéž, s. 218 .

58 Tamtéž, s. 207. Proto Aron vyzývá velmoci, že mají určitou povinnost blokovat jaderný výzkum na Blízkém východě, který je v „permanentním konfliktu“.

59 Týž: Les articles de politice international dans Le Figuro de 1947-1977. La Coexistence (mai 1955 à février 1965). Tome II, s. 847-852. 
kdy je v něm začleněno co nejvíce státu, jejichž řízení podléhá demokratické kontrole rozhodování. ${ }^{60}$

Vlastnictví atomových zbraní je podle Arona jen politickou zbraní nikoliv zbraní vojenskou. Pokud bychom se dívali na konflikt na Blízkém východě, při prosazování svého vlivu hraje vlastnictví atomových zbraní u západních zemí okrajovou roli. A to jak při získávání koncesí na těžbu ropy, tak při prosazování svobodného průjezdu Suezským průplavem, tak také při pomoci obrany Izraele. ${ }^{61}$

V případě Blízkého východu povede atomové soupeření k většímu napětí, které může mít jen dva výsledky. Pokud získají zbraně arabské státy jako odpověd’ na izraelské vlastnictví atomové bomby, stává se geograficky malá země Izrael velmi snadným cílem, vzhledem k okolnímu rozsáhlému arabskému světu. Jediný preventivní atomový útok na Izrael znamená jeho zkázu. Proto Izrael svým usilováním o vlastnictví atomové zbraně jen posiluje napětí v regionu, nutí Egypt se zajímat o atomový program. ${ }^{62}$ Aron byl velkým zastáncem podpory Izraele, který je dle něj jedinou zárukou stability regionu. Během Šestidenní války arabských států s Izraelem se veřejně postavil za podporu preventivního izraelského útoku na okolní arabské země a kritizoval francouzského prezidenta de Gaulla za jeho kritiku Izraele a jeho ignoraci vidět mezinárodní vývoj. ${ }^{63}$

Aron v šedesátých letech vnímal mezinárodní uspořádání v rámci určitého optimistického názoru, který vycházel z liberálního přesvědčení, že jednotlivé státy jsou svobodné v rozhodování, ale toto rozhodování je založeno na racionální úvaze, že hrozba atomového zničení zabrání totálním válkám mezi velmocemi. Proto jednotlivé státy budou tvořit aliance s atomovými velmocemi. Tak na úrovni subsystémů mohou probíhat mezinárodní krize, ale na úrovni celoplanetárního systému bude zachován mír. ${ }^{64}$

\section{Ekonomická hegemonie USA}

Tento článek postupně po dekádách mapuje vývoj Aronova myšlení o strategii mezinárodních vztazích. Proto i doba sedmdesátých let 20. století měla svá specifika v rámci studené války a byla charakterizována novými mezinárodně politickými vztahy. Zásadním místem střetu velmocí byla sice pokračující válka ve Vietnamu, ale ta chýlila k dohodě. Jinou oblastí byl region Blízkého východu, kde pokračující konflikt mezi židovským státem a arabskými sousedy vyústil v několik válek. Dle Arona tyto lokální konflikty doznívají a již nebudou hrát v mezinárodní politice velmocí tak zásadní úlohu. Souboj se přesouvá do oblasti ekonomické. O tom svědčí i fakt, že začala probíhat jednání o omezení jaderného zbrojení. Držení jaderných zbraní začalo být ekonomicky neefektivní. Proto Moskva s Washingtonem začaly jednat o snížení jejich počtu díky ekonomické náročnosti

60 Tamtéž, s. 1237-1240.

61 Tamtéž, s. 1385-1387.

62 Týž: Le Grand Débat, s. 238-239.

63 Týž: De Gaulle, Israël et les Juifs. Paris 1968.

64 Csizmandia, Sándor: L’interférence du liberalisme et du réalisme dans la pensée aronienne. In: Raymond Aron et la libérté politique. Actes du colloque international. Paris, s. 195-211. 
udržovat takový válečný program. Mezinárodní diplomacie velmocí se začala projevovat v ekonomickém soupeření. Ekonomická síla bloků se ukázala jako efektivnějším nástrojem mezinárodní politiky než armáda. Změnu rovnováhy sil Aron sleduje s předstihem dle ekonomických faktorů. ${ }^{65}$

Zájem velmocí se tak přesunul do posilování sféry ekonomického vlivu v regionech, at už Vietnam či Izrael. Sovětský svaz ztrácel v ekonomické oblasti síla a jeho zoufalým krokem o prokázání své síly byla na počátku osmdesátých let invaze do Afghánistánu. Aron přestal zkoumat planetární systém založený na rovnováze bloků, ale od 70. let se soustředil na analýzu samostatné politiky Spojených států. Zkoumal, jakými principy hegemon USA udrží svět mimo globální válku, když velmoci proti sobě ani při nejvyhrocenějších napětích vojensky přímo nevystoupily. $\mathrm{O}$ to více však na úrovni subsystémů podporovaly v konfliktních situacích své spojence. Válka v Izraeli v roce 1973 na svátek Jom Kippur toho byla příkladem.

Aron vždy vnímal státy jako jediné aktéry mezinárodní scény a mezinárodní systém nazýval systémem mezistátním (fr. interétatiques), nicméně od sedmdesátých let již mluvil o doplnění o vazby trans-národní, které byly formovány z velké míry i mezinárodními organizacemi. Studium mezinárodních vztahů předpokládá, že jednotliví aktéři, tedy státy, budou jednat podle dopředu odhadnutelných státních zájmů. ${ }^{66}$

Aron vycházel z realistické teorie a etatismu. Velmoci by se měly stát společným garantem uspořádání na Blízkém východě, Vietnamu a jiných válčících regionech. V možnosti vlivu velmocí na subsystémy vidí Aron příležitost, jak demokratický svět může rozšířit sféru vlivu jenom tím, že dopomůže konci konfliktů v regionech, které se ekonomicky pozvednou a dostanou se tak pod ekonomickou kontrolu. ${ }^{67}$ Teorie mezinárodní vztahů dle Arona nabízí nástroje k pochopení vývoje daleko více než povrchní dočasná analýza. ${ }^{68}$

Začátkem sedmdesátých let zkoumal vojenské strategie pruského generála Carla von Clausewitze (1770-1831), který se v době napoleonských válek jako jeden z prvních popisoval novou etapu evropských dějin z hlediska změn vojenské strategie a taktiky vedení válek. ${ }^{69}$

Clausewitz podle Arona nebyl jen vojenským teoretikem, jeho analýzy jsou filosoficko-historickým dílem, které je podle Arona inspirativní i v době lokálních konfliktů studené války. Jako první vytvořil nový koncept chápání konfliktů. Oproti francouzskému racionalismu, anglickému pragmatismu či německému idealismu a zformuloval realistický

65 Aron, Raymond: Histoire et dialectique de la violence, Paris 1973. Týž: Plaidoyer pour l'Europe décadente. Paris 1977.

66 Týž: Histoire et théorie des Relations Internationales. In: Týž: Leçons sur l'histoire. Cours du Collége de France. Paris 1989, s. 255-271.

67 Týž: Études politiques, s. 411-425.

68 Týž: République impériale, Les États-Unis dans le monde (1945-1972). Paris 1973. Týž: Historie XX. století, s. 332.

69 Tato doba je hodnocena jako počátek moderní diplomacie, srov. Kissinger, Henry: Uměni diplomacie. Od Richelieua po pád Berlínské zdi. Praha 1996. Aron v této době, kdy tehdejší velmoci proti sobě otevřeně nevystupovaly, ale o to více se soupeřily v diplomacii, spatřuje odraz bojovného míru, kdy velmoci, vědomy si vzájemného vlastnictví jaderných zbraní, nemohou proti sobě otevřeně vystoupit. Srov. Aron, Raymond: Penser la guerre, Clausewitz. I: L'Âge européen. II: L'Âge planétaire. Paris 1976. 
směr bez nadbytečných univerzálních teorií. ${ }^{70}$ Podle Arona lze moderní společnost pochopit lépe skrze konflikty. Když poznáme principy vojenské strategie, poznáme i strukturu moderní společnosti, s kterou jsou strategie spjaté. Aron byl tak řazen do skupiny tzv. neoclausewitiziánů.

Clausewitz po zkušenosti s napoleonskými válkami, kdy proti sobě bojovaly statisícové armády, pochopil, že s měnícím se stylem vedení válek se mění i myšlení celé doby. Vznikající nová společnost s sebou přináší i nové typy válek. Proto je na místě otázka po nové co nejefektivnější strategii, aby ztráty (ekonomické, vojenské) byly minimální. Soupeř se neměl zničit, ale spíše donutit, aby uznal sílu protivníka. K tomuto výsledku vede důkladné poznání soupeřových vojenských a politických možností a síly. Vytváří tak celkový obraz teorie války, aniž by dopředu dával morální hodnoty. ${ }^{71}$ Válku považoval za akt násilí s cílem donutit protivníka, aby se podřídil naší vưli. Násilí je tedy jen jedním z prostředků. Účel je vnutit nepř́íteli naší vưli. ${ }^{72}$ Zároveň je válka nástroj politiky, musí tedy mít nutně její povahu, musí nutně měřit její mírou. ${ }^{73}$

Clausewitz spojil vojenské strategie s určitým historicko-filosofickým obrazem doby. Jeho dílo není jen vojenskou př́ručkou, ale je to podle Arona i ekonomická, politická či sociologická teorie, ve které se odráží myšlení doby (fr. l'univers clausewitzien). ${ }^{74}$

Význam Clausewitze spočivá podle Arona v tom, že pod vlivem napoleonských válek a následného míru po Vídeňském kongresu odmítl dřívější pojetí války oddělené od politiky a ekonomie. Jako první upozorňoval na změnu stylu budoucích válek, kdy nově vzniklé národní státy budou pro obranu svých zájmů mobilizovat své občany v počtu miliónů. Tak upozorňoval na nebezpečí totálních válek mezi národy. Nejslavnější Clausewitzovou myšlenkou je teze, že válka je pouze pokračováním politiky jinými prostředky. ${ }^{75}$

Ústředním bodem Clausewitzových úvah bylo zdůraznění významu dlouhodobého strategického plánování, a tak i určení smyslu a cíle války. Strategie odpovídá rozložení sil protivníků a tak utváŕí mezinárodnímu postavení jednotlivých států se všemi jejich spojenci a protivníky. Efektivně zvolená strategie spočívá v oddělení dvou kategorií, které mohou na první pohled splývat - cíle (fr. l’objectif) a účelu (fr. objectif ultime). Cíle mohou být různé - vojenské, ekonomické či politické. V případě konfliktů je cíl zvolená vojenská krátkodobá taktika, jak porazit nepř́tele. Důležitější ovšem je, proč konflikt vznikl, jaké byly jeho kořeny, co je jeho účelem. Účel je tedy kategorie politická. Podle Arona právě

70 Aron, Raymond: Clausewitz et l'Etat. Annales. Economies, Sociétés, Civilisations, 32, 1977, p. 1255-1267, [online], (cit. 7. 7. 2009), dostupné na http://www.persee.fr/web/revues/home/prescript/article/ ahess_0392649_1977_num_32_6_293892.

Týž: Penser, s. 15, 331.

72 Clausewitz, C. von: $O$ válce, s. 23.

73 Tamtéž, s. 560

74 Srov. Aron, Raymond: Penser....I, c.d., s. 23.

75 Clausewitz, C. von: $O$ válce, s. 36. Clausewitz odvrhl pseudoteorie dř́vějších teoretiků a stratégů, jako byli Jean-Charles Chevalier de Folard (1669-1752), Dietrich Heinrich von Büllnow (1757-1807), Georg Heinrich von Berenhorst (1733-1814), ale dle Arona si Clausewitz všiml nové éry strategie spojené se jmény Antoine-Henri Jomini (1779-1869), dále pak Alexander Rüstow (1824-1866), Hans Delbrück (1848-1929), až k Alfredu von Schliefenovi (1833-1913), srov. Makers of Modern Strategy: From Macchiavelli to the Nuclear Age. Ed. P. Paret. Princeton 1986; Hart, Liddell: The Ghost of Napoleon. New Haven 1934. 
příčiny krvavých světových konfliktů 20. století vznikly na základě špatně zvolené strategie, kdy cíle byly vydávány za účely. ${ }^{76}$

Tak Clausewitz podle Arona přinesl do oblasti strategického uvažování nové „sociologické“ a „ekonomické“ podněty. Jako jeden z prvních pochopil, že typ války nemusí korespondovat s typem vládnoucích režimů, které válku vedou. Strategie se přizpůsobuje podle podmínek, druhu a účelu války, nezáleží na vládcích, ale na politice, která vytváří prostředí vedoucí $\mathrm{k}$ válce. ${ }^{77}$ Ve 20 . století ideologie pomátly cíle a účely. Umění války bylo nahrazeno totální válkou a strategie ustoupila ideologii. Ideologie, která nahradila strategii, zapříčinila oba světové konflikty.

Aron zkoumal recepci jeho myšlenek např. u Lenina (zabýval se principy revoluce a bojem tříd podle Clausewitzovy dialektiky), německých generálů Ludendorffa a Moltkeho (snažili se aplikovat zásady na vedení První světové války), Hitlera (inspiroval se principy vedení absolutní války) či Mao-Ce Tunga (inspiraci pro revoluční partyzánský boj). Tyto aplikace teorie do praxe ale byly nepochopením Clausewitzových myšlenek, který hovořil o umění války. Válku, i když se jedná o strašlivý stav společnosti, lze podřídit podle strategických principů a postupů, které dokážou protivníka eliminovat, aniž by se uplatňovala „taktika spálené země“.

Oceňoval na Clausewitzovi to, že varoval před absolutními totálními válkami, které s uměním války nemají nic společného. Tento typ válek se spoléhá jen na svoji absolutní sílu a nikoliv na taktiku a strategii. ${ }^{78}$ Obranou proti totálním válkám, jako byly První a Druhá světová válka je podle Arona záruka silné velmoci, která bude založená na demokratických, liberálních a neideologických zásadách. Bude schopna v rámci obrany svých mocenských zájmů účinně bránit ideologickému myšlení, které by bylo schopno iracionálně vyvolat válku.

V případě velmocenské politiky Spojených států nelze podle Arona hovořit o imperialismu, i přes to, že zahraniční politika USA nese znaky dominantní velmoci. Tím, že jsou USA založeny na liberálních demokratických principech, jsou vyloučeny imperialistické tendence evropských mocností 19. století nebo ideologické systémy. USA se jako světová velmoc poprvé definuje až s vlastnictvím atomových zbraní a jako jediná země je použila v přímém boji. Spojené státy zároveň disponují ohromnou ekonomickou převahou, převedenou do vojenské technologické převahy, která neustále v průběhu války zvyšuje. ${ }^{79}$

Na počátku soupeření se SSSR byl ,jen“ Marshallův plán, od sedmdesátých let jsou pro USA charakteristické vojenské základny po celém světě či schopnost vést války př́i-

76 Srov. Aron, R.: Penser, s. 108. Vztah mezi cílem a účelem určuje podle Arona také důsledky, jak válečný konflikt probíhá, zda se válka rozvine do války reálné či války absolutní. Před válkou absolutní varoval Clausewitz, před válkou absolutní v době nukleárních zbraní varuje i Aron. Tamtéž, s. 114.

77 Tamtéž, s. 374.

78 Aron, R.: Penser II, s. 50; zajímavá je Aronova analýza čínského myšlení, které vychází z taostické tradice střetu protikladů, kde bylo „umění války“ spojeno s uznáním protivníka, ale neměl být zničen, zcela proti evropské machiavellské tradici rozdrcení soupeře, Aron napřr. představuje, jak Mao-Ce Tung ve své ideologii spojuje účelově myšlenky marxismu s Clausewitzovým pragmatismem, jehož výsledkem je čínská forma komunismu. Srov. Tamtéž, s. 103-116.

79 Aron, Raymond: République impériale. Les États-unis dans le monde (1945-1972). Paris 1973. 
mo i nepřímo na několika místech najednou. ${ }^{80}$ Ve velmocenské politice USA je zásadní udržování hegemonie na základě přijatého předpokladu, že ani porážka armády nepřítele nemusí znamenat vítězství, proto jako velmoc jsou USA donuceny udržovat se stále v pozici hegemona. ${ }^{81}$

Na př́ikladu subsystému Blízkého východu se tato hegemonie ukazuje velmi plasticky na fatální asymetrii poměru sil mezi mocí Izraele jako spojence USA a arabskými sousedy jako spojenci SSSR. Pokud prohraje arabská strana nějakou z bitev či válek, konflikt pokračuje dál a poražený se připravuje k dalšímu střetu. Pokud by ale prohrál Izrael, znamenalo by to pravděpodobně konec jeho existence. Tuto asymetrii ukázala i válka Jom Kippur v roce 1973, kdy i přes moment překvapení arabského útoku Izrael díky pomoci USA a leteckému mostu nakonec tento konflikt vyhrál. ${ }^{82}$

Spojené státy začali být v pozici hlavního a jediné světové mocnosti a Sovětský svaz je donucen reagovat na kroky USA. Spojené státy díky technologiím a hospodářskému vývoji získaly nezpochybnitelný náskok. Síla západních evropských států je tak přímo úměrná síle Spojených států. Západní svět je závislý na americké politice. Tím, že se USA staly od 70. let podle Arona světovou velmocí číslo jedna, byly donuceny zefektivnit svou zahraniční politiku. Arona zajímá, v čem tato efektivita tkví. ${ }^{83}$

Při hodnocení úlohy USA se Aron nejvíce odvolává na analýzy francouzského sociologa 19. století Alexise de Tocquevilla, který žil v USA a predikoval způsob, jak se z USA stane světový hegemon. ${ }^{84}$ Tocqueville si všímal podstatných rysů americké společnosti, které jsou i po dvou staletích stále platné a které charakterizují společnost USA. Jedním z hlavních rysů této země je fakt, že je bez zátěže historického dědictví (feudalismus, kolonialismus, revoluce), má tak před evropskými státy výhodu snadnějšího přizpůsobení proměnlivé planetární diplomacii.

Spojené státy posouvaly své hranice obchodně a finančně, což byl efektivnější nástroj než vojensky ovládat cizí území, jak to dělaly evropské země v době kolonizací. Po roce 1945 a po začátku studené války se situace natolik změnila, že pro USA bylo efektivnější mít ve spřátelených zemích svoje základny propojené s jaderným arzenálem, a snížit náklady na udržování hegemonie na minimum - využívat co nejefektivněji kombinaci atomové hrozby a vědomí stálé prŕítomnosti u hranic nepřátel. Tak zahraniční politika USA ovládla planetární systém, který již nemá geografické hranice ${ }^{85}$

80 Aron, Raymond: Les Dernières Anées du siècle. Paris 1984. Týž: Historie XX. století, s. 459-476. Aron dále srovnává postavení mocností USA a SSSR a upozorňuje na ekonomické aspekty dominantní vlády v komunistickém či kapitalistickém bloku. Ty podle statistik jasně ukazují, že umělé politické udržování dominantní nadvlády je ekonomicky neefektivní a brzy se zhroutí. To dle Arona bude i osud komunistického bloku, který nerozlišuje mezi ekonomikou a politikou. Tamtéž, s. 503-511.

81 Aron, R.: Penser II, s. 195.

82 Tamtéž, s. 196.

83 Srov. Aron, Raymond: République, s. 12.

84 Srov. Tocqueville, Alexis de: Demokracie v Americe. I, II. Praha 1992. Zde zásadní úlohu sehrála Monroeova doktrína z roku 1823, která měla mít charakter anti-imperialistický, ale v očích neameričanů udělala z USA zemi s charakteristikou imperialismu, Aron, R.: République, s. 21.

Tamtéź, s. 35. 
Podle Arona diplomacie Spojených států připomíná strategii od jedné křížové výpravy k druhé. I přes to, že pováleční američtí prezidenti měli v dílčích záležitostech různý přístup, hlavní imperiální tendence USA se neměnily. Tento postoj je podle Arona založen právě na vojenské převaze a na vlastnictví technologií napojených na možnost jaderného arzenálu a na udržování leadership militaire. ${ }^{86}$

Nejrůznější státy se snaží a budou snažit získat technologii atomových zbraní jako zbraň zastrašení. Podle Arona politika USA s tímto stavem musí počítat, pokud chce hrát i v budoucnu úlohu světového hegemona. ${ }^{87}$ Lze ale předpokládat, že možný atomový konflikt povede podle zásad Clausewitzovy logiky k tomu, že nedonutí soupeře k bezpodmínečné kapitulaci a velice pravděpodobná jednání po skončení lokálního jaderného konfliktu by vedla k dohodnutí status quo ante bellum. Aron naznačuje, že až mezinárodní prostředí bude multipolární, zvýší se riziko převratů v nestabilním nedemokratickém státě, který vlastní atomové. Atomová bomba převratům a násilí nezabrání. ${ }^{88}$

Aron střízlivě hodnotil i přehnaně optimistické názory na konec studené války začátku osmdesátých let na Západě. Tvrdil, že nelze i přes dočasné úspěchy věřit v jednoznačně pozitivní budoucnost pro celý svět. ${ }^{89} \mathrm{~V}$ době počínajících jednání mezi USA a SSSR o odzbrojování a omezení jaderného arzenálu Aron zkoumal, jak se takové politické změny přenesou do boje o moc a na mocenskou politiku. Upozorňoval, že historie pádem železné opony neskončí a dovolával se Toynbeeho výroku „history is again on move“. Aron varoval před zjednodušeným pohledem na politiku, jejímž jediným cílem je humanismus a obrana lidských práv, které bezezbytku nejsou dodržovány nikde. V případě, že padne nedemokratický komunistický blok, neznamená to konečné vítězství demokracie. Mechanismy moci se modifikují. Obrana lidských práv je jistě záležitost chvályhodná pro jedince, kteří se tím zabývají profesionálně (novináři, aktivisté, představitelé neziskového sektoru) a kteří mohou tak ovlivňovat veřejné mínění, ale nikoliv pro strategii mezinárodní politiky. ${ }^{90}$

86 Tamtêž, s. 264; Aron zastával vždy názor, že by politika USA a Evropy měla být co do politického rozhodování sladěná, soupeření obou kontinentů je hrou s nulovým výsledkem, co jeden získá, druhý ztratí. Naopak ekonomickou spoluprací vydělávají oba, protože bohatá Amerika znamená bohatou Evropu. Aron, Raymond: L 'Europe face a la Crise des Sociétés Industrielles. In: Týž: L'Europe des Crises. Bruxelles 1976 , s. 77-142; Aron, Raymond; Heckschner August: Diversity of Worlds. France and the United States Look Their Common Problem. New York 1957.

87 Zastrašování (angl. deterrence) podle Arona tak můžeme rozdělit podle různých stupňů psychologická hrozba (z angl. intimidation), odrazování (z angl. dissuasion), přesvědčování (z angl. persuasion). Aron podrobně studoval materiály amerických vojenských strategií, které od 50. let podrobně nukleární strategii (z angl. nuclear strategy) rozpracovávaly, především práce Bernarda Brodieho (1910-1978), který do amerického prostředí uvedl Clausewitzovu teorii války. Dokonce na americkém ministerstvu zahraničí vzniklo speciální oddělení pro psychologii zastrašování (U.S. Department of Defense‘s Deterrence Operations).

88 Aron, Raymond: A l'âge atomique, peut-on limiter la guerre? In: Týž: Études politiques. Paris 1972, s. 479494.

89 Do této pasti optimismu se chytil o pár let později v době pádu komunistického bloku i americký politolog Francis Fukuyama, svojí „proslavenou“ tezí o „konci dějin“. Srov. Fukuyama, Francis: Konec dějin a posledni clověk. Praha 2002.

90 Aron, Raymond: Angažovaný pozorovatel. Rozhovory s Jeanem-Louisem Missikou a Dominiquem Moltonem. Praha 2002, s. 308-310. 
Aron stačil ještě před svou smrtí vydat své Paměti, které se staly na francouzských knižních pultech francouzským bestsellerem a i jakousi neoficiální učebnicí francouzské historie 20. století. ${ }^{91}$ Nové reedice tohoto díla dokazují, že dnes v době turbulentních změn, je třeba takových analytiků na rozbor mezinárodní situace jako byl Aron.

\section{Vliv Aronových mezinárodně politických názorů po skončení studené války}

Názory na jeho realistickou teorii se různí. Paradoxně jeho dílo získalo velký ohlas v anglosaském světě a zanechalo zde silnou stopu. Nevytvořil žádnou specifickou historickou nebo sociologickou školu, ale spíše svou obhajobou důsledné analýzy a exaktnosti. Tak ovlivnil jednotlivé teoretiky mezinárodních vztahů. Proto není hodnocen skrze teorii, ale skrze to, jak dokázal prezentovat konkrétní události světové politiky. ${ }^{92}$ Můžeme oceňovat jeho mezioborový přístup s důrazem na weberovskou rozumějící sociologii, kdy požadoval rozumět skutečnosti pomocí jasného vymezení pojmů, pochopit uspořádání mezinárodního společenství a rozpoznat jeho skrytá nebezpečí. ${ }^{93}$ Do zajímavých souvislostí se Aronovo dílo dostává ve vztahu k současné politice USA, kdy se diskutuje o Aronově úloze jako jednoho ze zdrojů neokonzervativního proudu v americké politice počátku 21. století. ${ }^{94}$

Tím jak Aron viděl vývoj realisticky a dokazoval, že války se budou opakovat tam, kde je mírové soužití jen křehkým a kompromisním uspořádáním, se ukazuje jako silný pacifista, který chce konfliktům předcházet a proto dokazoval, že multipolární uspořádání je nebezpečnější než bipolární. ${ }^{95}$ Jeho popis mezinárodní situace je nazýván jako popis soft-power, tedy mezinárodních vztahů, které nepovedou ke globální válce. ${ }^{96}$

91 Aron, Raymond: Mémoires. 50 ans de réflection politique. Paris 1983.

92 K Aronovu realistickému přítupu v metodologii mezinárodních vztahů se hlásil Aronův dlouholetý přítel Henry Kissinger (1923), profesor Harvardské univerzity žijící v Paříži Stanley Hoffmann (1928), sociolog Pierre Bourdieu (1930-2002) či teoretik mezinárodních vztahů Pierre Hassner (1933) a mnoho jiných. Nejvýstižněji popsal význam Arona bývalý americký ministr zahraničí Henry Kissinger, který po Aronově smrti prohlásil, že nikdo na něj neměl větší intelektuální vliv než Aron. I když ten Kissingera kritizoval vždy pregnantně, nebot Kissinger byl politikem (intelektuál se může mýlit, vydá novou knihu, ale politik se mýlit nemůže), Aronův souhlas Kissingera povzbudil, Aronova kritika ho krotila, srov. [online], (cit. 21.2.2010), dostupné na http://agora.qc.ca/mot.nsf/Dossiers/Raymond_Aron.

93 Srov. Badie, B.: Raymond Aron, s. 163-176. Rozumět mezinárodnímu společenství znamená podle Arona vrátit se ke klasickým pojmům politické filosofie, která definovala „přirozený stav“ oproti stavu „občanskému“, mezinárodní uspořádání se blíží více „stavu přirozenému“, vztahy mezi státy se dosud podle Arona nacházely v „přirozeném stavu“, který je protikladem (vnitrostátní) vlády zákona. Kdyby tomu tak nebylo, nebylo by možné vymezit konkrétní (politickou) teorii mezinárodních vztahů, srov. Guzzini, Stefano: Realismus v mezinárodních vztazich a mezinárodní politické ekonomii. Brno 2004, s. 19.

94 Srov. Vaïsse, Justin: République impériale, démocratie impériale : Aron et les néoconservateurs, intervention au colloque centenaire de Raymond Aron. EHESS, 11 - 12. Mars 2005, [online], (cit. 7. 7. 2009), dostupné na http://www.vaisse.net/BiblioJustin/Articles/BiblioJustin-ColloqueAron-12mars2005.pdf.

95 Badie, B.: Raymond Aron jako teoretik, s.163-176. Proto Aron podporoval vznik nových států rámci bloků, protože uznání suverenity v podobě státu je prostředkem zmírňování napětí uvnitř samotného bloku.

96 Hoffman, Stanley: Force, Legitimacy and Order, Brookings Institution. US-Europe Analysis Series, February 2005, [online], (cit. 13. 3. 2010), dostupné na http://www.brookings.edu/fp/cuse/analysis/ 
Význam Arona je v tom, že svým důrazem na zdroje mezinárodní politiky v mocenském napětí, které je v určité opozici vůči ideologickému zápolení, dokázal popsat mechanismy, které vedly ke konci komunistickému bloku, jako důsledek ztráty svého ideologického oprávnění. ${ }^{97}$ Bylo to dáno i tím, že Aron měl cit pro podstatu mezinárodního práva, sílu či slabost mezinárodních institucí..$^{98}$

Dnes je častý názor na Aronovy studie jako na př́liš složité a abstraktní. Nepochopením je, že to plyne z jeho snahy po celkovém popsání situace. Tento př́stup je nahrazován sestavováním dílčích studií a analýz, které se jen na Arona odvolávají kvůli akademické tradici. Proto je vnímán jako autor, který je více citován než čten..$^{99}$

\section{Závěr}

Tento př́íspěvek si kladl za cíl představit vývoj myšlení Raymonda Arona, který se zabýval po 40 let teorií mezinárodních vztahů. Své úvahy ale vždy dokládal na konkrétních př́kladech světové politiky. Aron se považoval za "angažovaného pozorovatele“ a svoje analýzy zakládal na detailním historickém a politologickém rozboru, který interpretoval pomocí principů rozumějící sociologie. Tento svůj přístup chápal jako popis tzv. „dějin př́tomnosti“. Aron analyzoval aktuální politickou situaci, převážně napětí či konflikt v regionech, kde zápasily o moc obě velmoci studené války, tak aby se vyhnuly otevřenému konfliktu. Takovouto situaci Aron zasadil do rámce širších vztahů, z kterých se ukazuje celkový obraz filosofie dějin, tedy proč se daný konflikt odehrává a jaké jsou prvotní př́činy a možné důsledky, které již běžný pozorovatel přehlédne.

Aron sice vycházel ze sociálních teorií a filosofie dějin, ale tak, aby díky nim mohl pozorovatel pochopit jejich důsledky v aktuální politice. Aron proto chápal teorii mezinárodních vztahů jako znalost, která umožňuje předvídat a podle toho jednat (fr. savoir pour prévoir et pouvoir). Jako zastánce demokracie a svobody, vnímal mezinárodní vztahy jako prostředí, kde v soupeření demokratického a totalitárního světa je větší možnost k prosazení demokratizačních tendencí. Upozorňoval na to, že k udržení demokracie je potřeba využívat realisticky co nejvíce prostředků diplomacie, mezi něž počítal i vlastnictví atomových zbraní či ekonomickou sílu dané země. Demokracie je větší zárukou

hoffmann20050201.pdf>. Srov. Malis, Christian: Raymond Aron et le Concept de Puissance. Institut de Stratégie Comparée. Commission Française d'Histoire. [online], (cit. 2. 3. 2009), dostupné na http://www. stratisc.org/act/Malis_POWERII.html.

97 Cesa, Marco: Realist Visions of the End of the Cold War: Morgenthau, Aron and Waltz. British Journal of Politics and International Relations, Volume 11, Number 2, May 2009, pp. 177-191(15), [online], (cit. 5. 5. 2009), dostupné na http://www.ingentaconnect.com/search/article?title=rAYMOND+ARON\&title_type $=$ tka\&year_from $=1998 \&$ year_to $=2009 \&$ database $=1 \&$ pageSize $=20 \&$ index $=2$.

98 Hassner, Pierre: Raymond Aron on use of Force and Legitimacy, CERI Sciences-Po, U.S. Europe Analysis Series, February 2005, [online], (cit. 5. 5. 2009), dostupné na http://www.brookings.edu/fp/cuse/analysis/ hassner20050201.pdf.

99 Srov. Frost, Bryan-Paul: Resurrecting a neglected theorist: the philosophical foundations of Raymond Aron's theory of international relations. Review of International Studies 23, 1997, č. 23, s. 143-166, [online], (cit. 23. 4. 2009), dostupné $\mathrm{z}$ http://journals.cambridge.org/action/displayAbstract?fromPage=online\&aid=33475. 
pro udržení míru než totalitární ideologie, které v jeho době ztotožňoval s nacismem a komunismem. Dnes, kdy žijeme v politicky multipolárně uspořádaném světě, kde hned několik velmocí aspiruje na úlohu světového politického lídra, je Aronova metodologie uvažování stále aktuálnější a potřebnější.

\section{Philosophy of Power Balance or Belligerent Peace According to Raymond Aron}

This article describes the work of french historian and philosopher Raymond Aron and concentrates on Aron's theory called himself as "history of presence". History of presence means in the methodological point of view analyzing facts for any actual political problem as an intersection of the past with the future. According to Aron no facts are historical isolated.

The article shows how this kind of approach Aron applied in the field of international relations during Cold War. Aron described philosophy of power balance between the two oposite political Powers - United States and USSR. Article focuses on presenting Aron's theoretical thinking about actual political problems in international relations when Cold War kept mutual balance between Powers, and emerged in regional conflicts only in regional subsystems. But never conflict araised to direct Powers confrontation. Aron called this state as "Belligerent Peace".

He claimed himself to be political conservative. But with deep sensation for democratical principles protecting minorities and human rights, which he understood deeply as a member of assimilated jewish family in France. He had to excape to London due to nazis occupation during Second World War. Aron emphasized realistic theory of international relations.

He combined in his thoughts more than one methodological approaches from sociology, politology, economy to philosophy and history. His analyses used to be not only academical theory, but Aron worked as independent adviser for french presidents Charles de Gaulle and Georges Pompidou, he touched the problems realistic. He declared some specific rules, which both Powers have to obey. He stated that international relations are not accidental. Cold War formed specific unalterable rules, which were formed by ownership of nuclear weapons. He interpreted temporaly forgotten war strategy analyses of Carl von Clausewitz or sociological synthesis about USA by Alexis de Tocqueville. Aron described Cold War as a part of the modern age, when in the international political strategy dominated principles, which originated in 19. century. 
